\title{
KIMBANGUISM: AN AFRICAN INITIATED CHURCH
}

\author{
Aurélien Mokoko Gampiot \\ CNRS-GSRL-EPHE, Sorbonne University \\ Institute for Signifying Scriptures, Claremont Graduate University
}

\begin{abstract}
During the early 1920s in what was then known as the Belgian Congo, a Christian revival movement was initiated by an African, a Baptist catechist named Simon Kimbangu, who immediately challenged the colonial order by preaching to and healing the local population. The Kimbanguist Church, an African Independent Church born from this movement, considers itself as a tool of identity reconstruction, empowering the believers to express their suffering and challenge the racial inequalities still extant in the post-colonial context. A member of the World Council of Christian Churches since 1969, with an estimated membership of 17 million today, the Kimbanguist Church has evolved, as the American sociologist Susan Asch explained, with two parallel dimensions. The first is made up of the educated minority, which is struggling to bring about theological reform, while the second one, composed of the tradition-oriented majority, has imposed popular beliefs, throwing the church into a conflict with the World Council of Churches since the year 2000 .
\end{abstract}

Key Words: Kimbanguism; African Initiated Church; Black Identity;

Holy Trinity; Incarnation

Kimbanguism was initiated in the early 1920s in what was then the Belgian Congo by Simon Kimbangu, a Baptist Catechist, who fought against the Belgian colonial order by preaching to and healing the local population. The prophet could only speak for six months until he was jailed for life. Yet, since 1959, the date of its official recognition by the Belgian authorities, the movement has developed into one of the main African Initiated churches, with an estimated membership of 17 million worldwide. The Kimbanguist Church is also recognized by the World Council of Churches, but most of its members display a number of beliefs which are specific to this religion.

This article aims to show how the balance of power is expressed between the missiology developed by the academic or theological elite of the church, and the traditional base sustained by popular, spontaneous beliefs. The analysis is based on fieldwork carried out both in the church's homeland in the Democratic Republic of Congo, and among congregations of the diaspora in Europe. It offers to decipher both the prophetic sermons of the spiritual leaders, and the church's inspired hymns, in order to account for this collective faith elaborated by the mass of believers and by pastors who may or may not be theologians. This religious phenomenon has been depicted in abundant scholarly literature, most importantly in the work of the French Africanist Georges Balandier, who analyzed it in its colonial context ${ }^{1}$. My own work ${ }^{2}$ contributes to the observation of the Kimbanguist 
church by following its evolution in space and time, with a specific emphasis on its relation to Blackness and its transnational dynamics.

To comprehend the Kimbanguist movement, it is necessary first to situate it in the genealogy of spiritual movements of resistance to the colonial order in the 1920s. The first section discusses the biographical and historical dimensions of the movement initiated by Simon Kimbangu, as well as the theological bases of Black restoration offered by the Kimbanguist Church. The second addresses the double hierarchy of the Kimbanguist Church: popular Kimbanguism v. modern reformist Kimbanguism, in order better to delineate its understanding of Black identity. The third and last one describes how the Kimbanguist Church includes a space for academic theology - expression still remains stifled by popular faith.

\section{Simon Kimbangu and Popular Faith in the 1920s}

In the beginning of Kimbangu's prophetic action was the Christian faith, which he taught as a Baptist catechist in his hometown, N'Kamba, in the south of what is now the Democratic Republic of Congo. Simon Kimbangu built a career as a spiritual guide over a rather long period. First, he read and commented the Bible for his fellow Congolese, in Congolese languages. On top of his position as a catechist, he had a mystical experience. He had visions and heard voices from Jesus Christ, who ordered him to convert his fellow Congolese. He first refused to accept this call from Christ, arguing that there were pastors among colonial missionaries who already carried out this mission. On 6 April 1921, he let this call guide him to work a miracle, healing a young woman named N'Kiantondo in the name of Jesus Christ.

Over time, he is said to have performed some other miracles including cases of resurrection of dead people. This prophetic action caused reactions from two categories of people: first, his fellow Congolese who subscribed to his movement. Then, religious colonial authorities, who were alarmed by this action of Kimbangu, put pressure on colonial authorities, who, in turn, arrested Simon Kimbangu and imprisoned him for life. He was transferred from his hometown to Lubumbashi, along with 37000 families of followers, who were forcibly deported. Kimbangu died in prison after 30 years on 12 October 1951.

Given the brief duration of his public life as a leader, it is worth investigating what established the original authority or leadership of Simon Kimbangu; for example, to what extent did his authority differ from the one we find in the established churches? How did this authority become sacralised in the Kimbanguist Church after his arrest?

First, it is important to specify that the charisma of Simon Kimbangu results from his miraculous healing powers. Anthropologists have demonstrated how illness is perceived as a factor of social disorder; hence it is not surprising to observe that the person who brings the cure restores, so to speak, the social order. Thus, it is not surprising to see that the acts of supernatural healing performed by Kimbangu led in turn to his being identified as a

See Aurélien Mokoko Gampiot, "Kimbanguism as a migrants' religion in Europe", in Christianity in Africa and the African Diaspora. The Appropriation of a Scattered Heritage, edited by Afe Adogame, Roswith Gerloff, Klaus Hock, London/New York: Continuum international, 2008:304-313. See also Les Kimbanguistes en Europe: d'une génération à l'autre, Archives des Sciences sociales des Religions, no. 143, July-September 2008:111-128, as well as my two books, Kimbanguisme et Identité noire, Paris: L'Harmattan, 2004 ; Les Kimbanguistes en France, Paris: L’Harmattan, 2010. Kimbanguisme et Identité noire, Paris: L'Harmattan, 2004; Les Kimbanguistes en France, Paris: L'Harmattan, 2010. See also the fieldwork conducted Anne Mélice in Belgium, David Garbin in London, and Benjamin Simon in Germany. 
saviour, bringing remedies to all the social troubles undermining Congolese society in the colonial time - oppression, epidemics, and absence of progress or science among Black people.

Then, the charisma of Simon Kimbangu is linked to a particular historical element: the context of his mission being a colonial one, Kimbangu's preaching focused on giving people a new message and new understanding of Christianity with eschatological promises. According to contemporary observers of Kimbangu, he was endowed with a strong personality and remarkable oratorical talent. So, Kimbangu did not just heal people, but preached against idols and witchcraft and condemned polygamy and lascivious dances - he fought against the colonial order, prophesying a better future for Blacks. As a result, awareness of the colonial predicament gave rise to a nationalist, anti-colonial movement not only among the natives of the Belgian Congo, but also among those of the French Congo and Angola (the Portuguese Congo.) These sentiments were expressed in terms of both nations and races. "N'gouzism (as Kimbanguism is known in Brazzaville) as a politicoreligious movement raised the question of race and created a nationalist consciousness in Congo. The idea of opposing Blacks and Whites and claiming Africa for the Africans has been embraced by the natives so earnestly that it seems it shall remain in their souls forever." 3

Finally, we can also note another significant element: because Simon Kimbangu was jailed at a great distance from his home region, this contributed to creating an increasingly idealized image of his person. The French Africanist George Balandier wrote that "the imprisonment and deportation of Simon Kimbangu, contributed much more in the increase of his power than in the destruction of the movement he had initiated. The imprisoned leader became an appropriate symbol for stimulating opposition (to the colonial rule); since he was deprived of any direct contact with the outside, the processes of idealization could work more freely, and his example even served to encourage others to dedicate themselves to the cause." Corroborating Balandier's remark, Kimbanguist collective memory depicts Simon Kimbangu as enjoying unhampered freedom of movement, due to his power of ubiquity, as the following passage from Diangienda Kuntima's 'green book' shows: “On Sunday, 2 October 1921, Muilu Marie came down with a strong fever, caused by a huge furuncle which had developed in one of her armpits. The jail physician was sent to her bedside... The physician who came to see her found her in prayer, surrounded by her three children. He jeered, 'How now, Simon Kimbangu's wife can't even get healed by the prophet?' He summarily looked at her furuncle, and sneered, 'you'd better call the miracle man (Simon Kimbangu), he can heal her; since he is said to have cured sick people by the thousands, he certainly can't leave his wife in such a sorry state!' After the interpreter had translated the doctor's blasphemous words for Marie Muilu, she simply answered, 'Go in peace, I know that God will not forsake my husband or anyone who believes in Him.' As soon as the physician had left, Muilu began praying and we suddenly saw Simon Kimbangu before us, appearing as if by magic. He touched the furuncle with his hand, and his wife's armpit was sound again. The furuncle had disappeared instantly, and the fever was gone. No one knows how, nor by whom the doctor soon learnt that Muilu was in good health again. He came back to the jail and had to admit that Muilu's furuncle had mysteriously disappeared. The bewildered physician simply said, 'Maybe we are mistaken about

Jaffré, Journal of the community of the small seminary of M'bamou (Congo-Brazzaville), 1930.

Georges Balandier, The sociology of Black Africa; social dynamics in Central Africa, translated by Douglas

Garman, New York: Praeger Publishers, 1970. 
Kimbangu?',

Apart from this well-known testimony by his son Diangienda, many others buttress the belief in Kimbangu's ubiquity and supernatural essence. In the eyes of his followers, he was physically a prisoner, but he continued his mission supernaturally, by being present in several places at the same time.

A well-known story in Kimbanguist milieus contends that on 24 April 1942, Kimbangu, while already a prisoner in Lubumbashi, was simultaneously arrested in several different places: Boma, Matadi, etc. He broke out supernaturally the next day by smashing the metallic door and leaving three shirts behind. This myth is considered as a reality, because 40 years later, in 1982, the Zairian government returned these shirts to the Kimbanguist Church, delivering them in person to the spiritual leader Joseph Diangienda. To this day, Simon Kimbangu is still said to make apparitions: the latest, to my knowledge, dates back to October 2009, when an eighteen-year-old Catholic man called Mbuta claimed to have been in contact with Simon Kimbangu for as long as he could remember - since he was 3 months old, his mother confirmed in an interview. His testimonies were corroborated by his relatives and neighbours in Kinshasa, who claimed to have witnessed the apparitions of Simon Kimbangu when he paid his regular visits to the young man. ${ }^{6}$

Another element confirming the reality of Kimbangu's apparitions is the existence of the Mandombe writing, which was discovered in 1978 by a Catholic man (who later converted to Kimbanguism) who claims to have experienced a miraculous conversation with Simon Kimbangu.

Besides, the myths relative to Simon Kimbangu's identity are elaborated freely and shape his persona, even attributing him a prenatal existence on the basis of the meaning of the name Kimbangu, i.e., "the one who reveals the hidden meaning of things." This name was chosen by his parents Kuyela and Luezi; Simon Kimbangu, born (according to a revelation given to the believers) on 12 September 1887, was their only child. At the time, children seldom bore the names of their parents, but were given meaningful names and were expected to behave in keeping with these. The believers' collective memory recalls a traditional healing ritual called Kimbangu fula mwana, literally "Kimbangu blows life into the child." These words are spoken in a ritual by which certain tribes implored Kimbangu to resurrect a stillborn child. Hence, Kimbangu's name entailed a sort of predestination to his calling. Marie Louise Martin offers the following analysis: "Kimbangu is said to have been given the name because he was one of these still-born babies who was called to life through shouting this name." 7 Kimbanguists object that many still-born babies who were brought back to life through this ritual were not called Kimbangu. Likewise, several authors saw Kimbangu as having inherited the art of healing from his father, who allegedly was a witchdoctor, as well as his mother and aunt who supposedly were healers. But Marie Louise Martin concludes: "All these are attempts to place Kimbangu among the many traditional African witchdoctors and healers. However, we must take account of the historical facts and see how these have been transformed." 8 Kimbanguist oral history records that Simon Kimbangu drew attention from a very early age by behaving in extraordinary ways. For instance, at the age of five, he allegedly told his father, "before you

Ibid, 103 .

Interview by César Guinamu, Emission ya ba zoba, vol. 21.

Marie Louise Martin, Kimbangu, An African Prophet and His Church, translated by DM Moore,

Oxford: Basil Blackwell, [1971] 1975:42.

$8 \quad$ Ibid, p.41. 
were born, I was," "9 which seems to betray the existence of a conflict with him. Simon Kimbangu's mother, having died shortly after his birth, he was raised by his paternal aunt Kinzembo, who had recently converted to Christianity; this is how he was raised a Christian and joined the Baptist Missionary Society of Gombe-Lutete as a catechist.

All these mythical elements and experiences are well-known and maintained by the Kimbanguist collective memory; they tend to legitimize Simon Kimbangu's authority as an outstanding spiritual guide. During the thirty years of his confinement, the leadership of the fledgling movement was taken over by his wife Muilu Marie, but she did so as an interim clandestine leader, without betraying any personal ambition. She effectively behaved as the shepherd of the flock, keeping her husband's followers in the faith in his return, and raising her sons on her own until they were ready to take over the leadership of the movement. They had already done so when Kimbanguism was granted official recognition by the Belgian government, on an equal footing with the Catholic and Protestant mother churches. As a result, the young church developed with a dual identity, with on the one hand, strong collective beliefs in the transmission of Kimbangu's charisma to his sons, and on the other hand, a less traditional, reform-oriented hierarchy.

\section{The Three Sources of Kimbanguist Faith}

The Kimbanguist church is based on three theological sources which shape the believers' religious psyche. These are the Bible, the church's inspired hymns, and the prophetic speeches of the spiritual leaders.

Significantly, Simon Kimbangu himself had recommended the daily reading of the Bible shortly before he was arrested, in the following terms: "The Spirit has revealed to me that the time has come now for me to surrender myself to the authorities. I will leave you nothing but the Bible. Read it at all times and in all places, and put God's Commandments into practice unfailingly". ${ }^{10}$ Hence, the Bible is the reference book in the Kimbanguist church, as in any Christian church, but in this case, it involves the believers in the process of reappraising and critiquing their racial identification. Indeed, the Kimbanguist message is rooted in a Bible which has been re-read and interpreted. As Georges Balandier explains, "resorting to the Bible allows utopian constructions, and the belief in the salvation of the Black race under the guidance of prophets who are also the founders of the churches."11 Yet the Bible is also crucial in defining Kimbangu's identity, noticeably because the promise of Jesus Christ to send another comforter in John 14:15-17 is reinterpreted by Kimbanguists, who see Simon Kimbangu as the personification of the third person of the Holy Trinity - in other words, the Holy Spirit.

The second support is a vast corpus of inspired songs giving instructions received from God, or from Kimbangu, through inspired persons. These persons are chosen by God independently from their will and regardless of gender, professional and marital status, age or education. In dreams or visions, they 'receive' songs that define the beliefs of the church and give the believers a vision of the world which includes a revelation of the past, a reading of the present and an announcement of the future. These songs have a history of

\footnotetext{
Diangienda Kuntima, excerpt from the speech delivered to the church members on the centennial of the birth of Simon Kimbangu at the Kinshasa Conference Centre of the Kimbanguist Church, 12 September 1987.

10 Diangienda Kuntima, Histoire du Kimbanguisme, Editions Kimbanguistes, Kinshasa, 1984:82. Translation by Cécile Coquet-Mokoko.

11 Georges Balandier, op. cit., p. 425.
} 
their own, which began in 1921 when Kimbangu was challenged by the Protestant Reverend Jennings, who had observed that all his preaching, speeches and healing sessions were accompanied by Protestant hymns. Jennings had walked up to Kimbangu and challenged him in these terms, "How is it that Jesus, who gave you the power and strength to resurrect the dead, has deprived you of hymns so that you have to resort to ours?"12 Kimbangu withdrew for a moment to pray, and then returned with a new song in Kikongo, which is considered today as the very first Kimbanguist hymn. Here are the lyrics of one stanza of this hymn:

\section{E nkunga mia mbasi mubonga}

Nuisa tamboula makanda ma nza

O Yesu kunu wonza kesa

\section{Kenu vila kana ko}

\section{Sing the songs of the angels! You shall welcome all nations: This is Jesus' ultimate promise, Never forget this.}

This hymn, which sounds like a commandment, was the first of a seemingly endless series of sacred songs owned by the Church - today there are several thousands of them. The messages of the hymns, along with the prophetic and eschatological speeches of the leaders of the church, maintain the believers in the hope that the outcome of Black people's tribulations is the everlasting happiness of all African-descended people, and more specifically, the happiness of Kimbanguists. The hymns provide the believers with revelations of past events, an understanding of current ones, and announcements of future ones.

But the deciphering of both the inspired songs and the Bible is supplied by the prophetic words of the spiritual leaders, particularly those of Joseph Diangienda Kuntima, who constitute the third support of the Kimbanguist faith. Simon Kimbangu and his wife had three sons who succeeded him; but it is the youngest who, from the late 1950s to his death in 1992, left his imprint most clearly on the church and in the believers' minds.

Jean-Claude Froelich has rightly emphasized the role of Simon Kimbangu's major successor: "Joseph Diangienda is the person responsible for the openly and deeply religious aspect now presented by a movement that was initially clearly revolutionary and antiWhite. He took Baptist teachings and engrafted on them the revelations of his father Simon; hence this is a profoundly Africanized Protestant church, but with a modernist, and even Western, streak."13 Joseph Diangienda Kuntima's numerous sermons, as well as the Bible (which he has interpreted in an Afrocentric sense) and the church's inspired hymns (many of which are attributed to his spiritual guidance) have indeed been, to this day, the major theological source articulating Black restoration for the Kimbanguist believers.

The three sources of Kimbanguist faith all contribute in shaping the members' religious psyche, and consequently, their relation to God, social life, and the founding figures of Kimbanguism, in particular Simon Kimbangu's three sons. Indeed, the hierarchical structure of the Kimbanguist church displays two facets: an official church with legal texts, and a traditional church for which the authority of tradition, and in particular the biological lineage stemming from Simon Kimbangu, tend to prevail over the former hierarchical order.

\section{The Double Hierarchy of the Kimbanguist Church: Popular Kimbanguism versus Modern Reformist Kimbanguism}

\footnotetext{
12 Diangienda, op cit.

13 Jean-Claude Froelich, Nouveaux Dieux d'Afrique, Paris: Editions de l'Orante (1969:68). Translation by Cécile Coquet-Mokoko.
} 


\section{The Status of the Spiritual Leader in the Kimbanguist Church}

For Kimbanguist believers, the status of spiritual leader is two-faceted insofar as it is at the same time based on legal texts and ecclesiastical functions, and traditional to the extent that it implies a sacred function on top of the ecclesiastical function. On the one hand, on the basis of legislation, the spiritual leader is a public persona who fills an administrative and public function. On the other hand, the spiritual leader is a traditional leader whose rights and duties, prerogatives and responsibilities, privileges and obligations depend solely on traditional charismatic skills.

In this respect, he is recognized as possessing the gifts of clairvoyance, mediumship (he speaks with the dead and knows about their afterlife), healing powers (he cures and resurrects the dead), the ability to interpret signs and decipher omens (he advises people and tells the future). Finally, he reveals his supernatural identity through inspired songs, dreams, visions, and even apparitions, because just like Simon Kimbangu, he is supposed to have the gift of ubiquity. All these charismatic gifts are deemed hereditary; hence, they confer to the leader a traditional legitimacy while myths about Kimbangu play a dominant role in strengthening his successors' aura.

The question now is thus to know how Simon Kimbangu is perceived today by the Kimbanguist Church. What is the official position of the Church on Simon Kimbangu?

The spiritual role of Simon Kimbangu is revealing of a distinction between what the American sociologist Susan Asch calls 'official Kimbanguism' and 'the Kimbanguism of Kimbanguists': "the opposition hinges on the spiritual role attributed to the prophet Simon Kimbangu: intermediary of the Africans with Christ or embodiment of the Holy Spirit. While apparently simple, this key concept is fundamental, because it is revealing of the actual gap which separates the Christo-centric orientations of the circle of reformist leaders, on the one hand, and the Kimbango-centric traditions of the overwhelming majority of the Kimbanguist followers, on the other hand.",14

This analysis, which the American sociologist made in 1983, does not contradict the current aspect of Kimbanguism. The only difference is that the transformation process emphasizes a single discourse, supported by the overwhelming majority of believers who contain the Christo-centric current, led by the educated class and in particular the theologians.

\section{The Place of Academic Theology among Kimbanguists}

Marie-Louise Martin, the Swiss theologian and missiologist quoted earlier, was not just one of the scholars who observed the Kimbanguist church and commented on its specificities. She had initially written her doctoral thesis on "the Biblical concept of messianism and messianism in South Africa" 15 and taught at the university of Roma in Lesotho; then she was driven out of South Africa because of her criticism of apartheid. Eventually, in 1968, she placed herself in the service of the Kimbanguist Church - in Congo-Kinshasa, where she created the Kimbanguist divinity school and became the first dean, with the sole intention of training ministers. Among all the works she published on this church, her most important book is Simon Kimbangu, An African Prophet and His Church, first published in German in 1971. Her resolve to train ministers bore fruit, because since the creation of this

\footnotetext{
14 Susan Asch, L'Église du prophète Kimbangu, de ses origines à son rôle actuel au Zä̈re, Paris: Karthala 1983.

15 Marie Louise Martin, The Biblical concept of Messianism and Messianism in Southern Africa, Morija Sesuto, 1964.
} 
divinity school, the Kimbanguist Church has boasted African ministers who are also theologians.

As a result, inside the Kimbanguist church there are two categories of pastors: the first one is constituted of some people from the community, who have distinguished themselves by their calling and their regular participation in the activities of church. They are appointed (or nominated for an appointment) by the spiritual leader. The second category of pastors is composed of theologians who received their education at the Kimbanguist divinity school, and were trained by Congolese as well as Western elites. The majors chosen by these students are often focused on African reality and cultures, and Kimbanguist faith. Having dedicated their lives to their calling, they are completely dependent on the church for financial support.

But what can be the weight of theologians equipped with this form of training, face to the Kimbango-centrism shown by the popular base?

It is important to stress that pastors from the Kimbanguist divinity school are less wellperceived by the base, because of the white influence correlated to their background. For the educated Kimbanguist milieu, Marie Louise Martin was sent by the World Council of Christian Churches to train anti-Kimbanguist pastors, because some theologians from the Kimbanguist divinity school don't believe or have difficulty believing that Simon Kimbangu is the incarnation of the Holy Spirit.

While Simon Kimbangu is perceived as the embodiment of the Holy Spirit, this is not what appears in texts written by the official Kimbanguist church: neither in its catechism, which was established in 1963, nor in its text of membership in the Ecumenical Council in 1969, nor even in the Kimbanguist reference book, which is the history of Kimbanguism written by J Diangienda in 1984, and even less so in the 63 resolutions adopted by the Kimbanguist Church in October 2002 after a general meeting. In all of these documents, Simon Kimbangu is referred to as 'saint' or 'messenger of Jesus.' It is only when focusing on the 'Kimbanguism of Kimbanguists' that one finds the assertion of the divine nature of Simon Kimbangu surfacing everywhere - in speeches, beliefs, legends and narratives, dreams, visions, and especially in the inspired hymns.

These two discourses coexisted peacefully, so to speak, up to the 1990s. But from the year 2000, the Kimbanguist authorities ceased to abide by the official doctrine, and decided to officialize and consecrate the popular faith. The starting point was the change of the date of Christmas to Kimbanguists: from then on Christmas has been celebrated on 25 May, which is the birthday of Dialungana, the second son of Kimbangu and spiritual leader at that time, who was identified by believers as the reincarnation of Jesus Christ. Since then, the educated minority has been struggling to bring about theological reform; but the tradition-oriented majority has imposed its popular beliefs, throwing the church into a conflict with the World Council of Christian Churches since the year 2000. Besides this critical situation with the World Council of Christian Churches, the succession crisis affecting the Kimbanguist Church also has observable repercussions on the evolution of popular theology. 
Kimbanguism Today: The Implications of the Succession Crisis on Kimbanguist Theology

Because Simon Kimbangu's charisma was understood as hereditary, a succession crisis began after the death of the last of the founder's three sons, Paul Dialungana, in 2001. The succession process took place out of the control of the clergy, during a family gathering of the grandchildren of Kimbangu which resulted in designating the eldest of the male descendants of the founder - Simon Kimbangu Kiangani, son of Dialungana - as the new spiritual leader and legal representative of the church, while all the other grandchildren appointed themselves as deputy spiritual leaders. But a year later, in 2002, the spiritual leader summoned the members of clergy to an extraordinary general assembly, which the other grandchildren of Kimbangu were not invited to attend. This general assembly ratified 63 'resolutions' giving a new orientation to the church by shifting its theology away from the ideology of descent, which gave a pre-eminent role to the 25 other grandchildren of Simon Kimbangu as heirs to his spiritual and healing powers. The clergy thus officially confirmed Simon Kimbangu Kiangani as the single spiritual leader and stripped all the other descendants of the founder of their titles as deputy spiritual leaders.

Not only did the Kimbanguist church modify the spiritual leader's judicial and legal status, but the explanation of the 63 resolutions to the church members was tied to an ideology of descent in which Simon Kimbangu Kiangani claimed to be the reincarnation of his grandfather as well as his uncle Diangienda Kuntima. Myths have circulated to buttress this ideology. The first mythical element is his name - Simon Kimbangu Kiangani, which includes that of the founder - and his date of birth, which allegedly coincides with the date of his grandfather's death, i.e. 12 October, 1951. This element allows those who contribute in consolidating the myth to identify him with his grandfather. But while the spiritual leader is buttressing his spiritual legitimacy as the only person competent to fill the capacity of sacred leader in the traditional Kimbanguist sense of the term, his cousins are building a parallel myth - that of family consensus among all the members of Simon Kimbangu's biological family, who claim to embody their grandfather whenever they are all together.

The last mythical element justifying Simon Kimbangu Kiangani's special status as spiritual leader and reincarnation of the founder is the set of traditional skills inseparable from spiritual leadership in the Kimbanguist church. Indeed, he claims to be the only one among the founder's grandchildren to possess the gift of 'double sight' (i.e. seeing both the visible and the invisible,) be a psychic, and be able to prophesy, heal, and reveal his godliness through visions, dreams, and inspired hymns. Yet, popular Kimbanguist theology today is expressed in two distinct ways among the church members. On the one hand, the official church upholds the traditional myth of a continuum of reincarnations of Simon Kimbangu through his son Diangienda Kuntima and his grandson Simon Kimbangu Kiangani. On the other hand, the parallel church (known as 'the side of $26=1$ ', ) led by the latter's cousins, contends that Simon Kimbangu's reincarnation keeps taking place only when all of his grandchildren are united in consensus.

As a result, the Church of Jesus Christ on Earth by His Special Envoy Simon Kimbangu (EJCSK) has developed by considering itself as a tool of construction of a new religious frame of reference. Even in the crisis which is affecting it now, founding myths remain deeply embedded in the members' collective psyche while beliefs and traditions keep nourishing popular Kimbanguist theology. 


\section{Conclusion}

In conclusion, tradition is the bedrock of the religious authority wielded by ecclesiastical or spiritual leaders in the Kimbanguist church. Within tradition, myths play a predominant role in shaping the charisma of a religious leader. Thanks to myths, the authority of the leader is established and he is enabled to command the loyalty and obedience of the believers. The main axis of this charismatic domination is the relation between leader and believer, which is actually rooted in the ideology of filiation. The spiritual power of the guide consists in his monopolizing the relation to Simon Kimbangu, the founder, who becomes conflated with the universal God. All these elements allow us to understand on the one hand the problem of the transmission of the spiritual power and on the other hand the problem of succession at the head of the church - both having at the same time a biological dimension (linked to lineage) and a spiritual one, connected to a realm that escapes the gaze of the sociologist, in other words: the invisible world.

\section{BIBLIOGRAPHY}

Asch, Susan 1983. L'Église du prophète Kimbangu, de ses origines à son rôle actuel au Zaïre. Paris: Karthala.

Balandier, Georges 1970. The sociology of Black Africa; social dynamics in Central Africa, translated by Douglas Garman. New York: Praeger Publishers.

Diangienda Kuntima, Joseph 1984. Histoire du Kimbanguisme. Kinshasa: Editions Kimbanguistes.

Froelich, Jean-Claude 1969. Nouveaux Dieux d'Afrique. Paris: Editions de l'Orante.

Garbin, David and John Eade 2007. "Reinterpreting the Relationship Between Centre and Periphery: Pilgrimage and Sacred Spatialisation among Polish and Congolese Communities in Britain". Mobilities, II-3:413-424.

McGaffey, Wyatt 1983. Modern Kongo Prophets Religion in a Plural Society. Bloomington, Indiana University Press.

Martin, Marie Louise 1964. The Biblical Concept of Messianism and Messianism in Southern Africa. Morija: Morija Sesuto.

Martin, Marie Louise [1971] 1975. Kimbangu, An African Prophet and his Church, translated by DM Moore. Oxford: Basil Blackwell.

Mélice, Anne 2000. Le kimbanguisme: un millénarisme dynamique de la terre aux cieux Actes de la Conférence internationale. Mouvements millénaristes en Afrique et dans la diaspora. Association belge des Africanistes/Belgische Vereniging van Afrikanisten, Académie Royale des Sciences d'Outre-Mer, Bruxelles, 30 November-1 December 2000. Bulletin des Séances de l'Académie Royale des Sciences d'Outre-Mer, No. 47:35-54.

Mokoko Gampiot, Aurélien 2008. "Kimbanguism as a Migrants' Religion in Europe”, in Christianity in Africa and the African Diaspora. The Appropriation of a Scattered Heritage, edited by Afe Adogame, Roswith Gerloff, Klaus Hock. London/New York: Continuum international, 304-313. 
Mokoko Gampiot, Aurélien 2004. Kimbanguisme et Identité noire. Paris: L'Harmattan

Mokoko Gampiot 2010, Aurélien. Les Kimbanguistes en France. Paris: L'Harmattan.

Simon, Benjamin 2001. "Christian Pluralism and the Quest for Identity in African Initiated Churches in Germany," paper presented at the conference "The Spiritual Supermarket: Religious Pluralism in the $21^{\text {st }}$ Century" organized by the CESNUR, April 19-22, 2001, http://www.cesnur.org/2001/london2001/simon.htm 